\title{
Bioefficacy of newer insecticides and biopesticides against brinjal shoot and fruit borer Leucinodes orbonalis Guenee (Lepidoptera : Pyralidae)
}

\author{
J.P. SINGH*, P.K. GUPTA, U. CHANDRA AND VIMAL KUMAR SINGH \\ Department of Entomology, N.D. University of Agriculture and Technology, FAIZABAD (U.P.) INDIA
}

\section{ARITCLE INFO}

Received : 30.12 .2015

Revised : 01.02 .2016

Accepted : 15.02 .2016

KEY WORDS :

Bacillus thuringensis, Leucinodes. orbonalis, Verticellium lecanii,

Beauveria bassiana, Biopesticides

*Corresponding author:

\begin{abstract}
A field experiment were carried out for two consecutive Rabi seasons 2013-14 and 2014-15 at Student's Instructional Farm, N.D. University of Agriculture and Technology, Kumarganj, Faizabad (U.P.). Among the various insecticides evaluated against brinjal shoot and fruit borer (L.orbonalis), Emamectin benzoate 5 SG @ 12.5g a.i./ha treated plots showed lowest infestation and gave higher fruit yield (253.12) followed by Flubendiamide 480 SC (249.33) and Novaluron 10 EC (243.63). The boipesticide NSKE 5 per cent most effective followed by Bacillus thuringensis, Verticellium lecanii and Beauveria bassiana. The highest cost: benefit ratio was obtained from NSKE 5 per cent (1:24.40) followed by Indoxacarb 14.5 SC (1:24.13) and Emamectin benzoate 5 SG (1:24.03) which were also economical than other treatments.
\end{abstract}

How to view point the article : Singh, J.P., Gupta, P.K., Chandra, U. and Singh Vimal Kumar (2016). Bioefficacy of newer insecticides and biopesticides against brinjal shoot and fruit borer Leucinodes orbonalis Guenee (Lepidoptera : Pyralidae). Internat. J. Plant Protec., 9(1) : 1-7. 